\title{
The impact of previous live births on peripheral and uterine natural killer cells in patients with recurrent miscarriage
}

\author{
B. Toth $^{1 \dagger}$, K. Vomstein ${ }^{1,2^{*}}$, R. Togawa ${ }^{2}$, B. Böttcher ${ }^{1}$, H. Hudalla ${ }^{3}$, Th. Strowitzki ${ }^{2}$, V. Daniel ${ }^{4}$ and R. J. Kuon ${ }^{2}$
}

\begin{abstract}
Background: Peripheral and uterine natural killer cells (pNK and uNK cells) are key players in the establishment and maintenance of pregnancy and are disturbed in patients with recurrent miscarriage (RM). Different immunologic risk factors have been proposed between patients with primary RM (pRM, no previous live birth) and secondary RM (sRM, $\geq 1$ previous live birth). However, so far, the study populations mainly consisted of small subgroups. Therefore, we aimed to analyse pNK and uNK cells in a large, well defined study population within a prospective study.

Methods: In total, $n=575$ RM patients ( $n=393$ pRM, $n=182$ sRM) were screened according to a standard protocol for established risk factors as well as pNK and uNK cells. Peripheral blood levels of $\mathrm{CD}_{4} 5^{+} \mathrm{CD} 3^{-} \mathrm{CD} 56^{+} \mathrm{CD} 16^{+}$ NK cells were determined by flow cytometry and uterine CD56 ${ }^{+}$NK cells by immunohistochemistry in mid-luteal nonpregnant RM patients. Exclusion of patients with $\geq 1$ established risk factor revealed $n=248$ idiopathic RM patients (iRM, $n=167$ primary iRM (ipRM), $n=81$ secondary iRM (isRM)).

Results: Patients with pRM and ipRM showed significant higher absolute numbers and percentages of pNK cells compared to sRM and isRM patients (pRM/ipRM vs sRM/isRM, mean \pm SD / $\mu l: 239.1 \pm 118.7 / 244.9 \pm 112.9$ vs $205.1 \pm$ 107.9/206.0 $\pm 105.6, p=0.004 / p=0.009 ;$ mean \pm SD \%: $12.4 \pm 5.5 / 12.8 \pm 5.4$ vs $11.1 \pm 4.6 / 11.1 \pm 4.3, p=0.001 ; p=0.002)$. Only patients with isRM showed significantly higher uNK levels compared to patients with ipRM (mean $\pm \mathrm{SD} / \mathrm{mm}^{2}$ $288.4 \pm 239.3$ vs $218.2 \pm 184.5, p=0.044$ ).

Conclusions: The demonstrated differences in pNK and uNK cells in RM patients depending on previous live birth might indicate differences in NK cell recruitment and potentially different underlying immune disorders between pRM and sRM. As there is an overlap in the distribution of the NK cell results, further studies with focus on NK cell function are needed in order to clearly identify RM patients with distinct immune abnormalities. The clinical relevance of our findings should be interpreted cautiously until specificity and sensitivity are further evaluated.
\end{abstract}

Keywords: Natural killer cells, Recurrent miscarriage, Immune status, Endometrium, Immunolog

\section{Background}

Recurrent miscarriage (RM) can be differentiated in primary and secondary RM: primary RM (pRM) refers to patients with no successful pregnancy whereas secondary RM (sRM) refers to patients with at least one live birth

\footnotetext{
* Correspondence: thomas.vomstein@i-med.ac.at

Toth $B$ and Vomstein $\mathrm{K}$ are joint first authors

${ }^{\dagger}$ Toth $\mathrm{B}$ and Vomstein $\mathrm{K}$ this authors contributed equally

'Department of Gynecological Endocrinology and Reproductive Medicine,

Medical University Innsbruck, Anichstrasse 35, 6020 Innsbruck, Austria

${ }^{2}$ Department of Gynecological Endocrinology and Fertility Disorders,

Ruprecht-Karls University Heidelberg, Im Neuenheimer Feld 440, 69120

Heidelberg, Germany

Full list of author information is available at the end of the article
}

before the miscarriages. Standardized protocols for exclusion of established risk factors in RM do not make this clinical distinction despite differences in immune regulation [1] and responsiveness towards leucocyte immunization [2] between pRM and sRM patients. As only half of RM patients can be offered targeted treatment (in about $50 \%$ of patients the cause for RM cannot be identified) we need to rethink our clinical categorization.

Natural killer (NK) cells are promising new risk factors in RM and belong to the innate immune system. They are characterized by the expression of the surface marker CD56 [3]. There are two populations that can be

(c) The Author(s). 2019 Open Access This article is distributed under the terms of the Creative Commons Attribution 4.0 International License (http://creativecommons.org/licenses/by/4.0/), which permits unrestricted use, distribution, and 
distinguished: peripheral NK and uterine NK cells (pNK and uNK cells). PNK cells show a strong cytotoxic activity with known antiviral and antineoplastic effects and are phenotypically and functionally different from uNK cells. UNK cells are less cytotoxic and have a different profile of secreted cytokines and receptor/gene expression, such as killer cell immunoglobulin-like receptor (KIR), human leukocyte antigen-C (HLA-C), HLA-E, and HLA-G. Both, pNK and uNK cells possess immunomodulatory functions $[4,5]$. While some studies analyse NK cells as percentages of total lymphocytes, others report absolute numbers [4]. As differences were shown in percentages as well as in absolute numbers, it is advised to analyse both [4]. Ranges of NK cells are reported to vary widely and pNK cells are not routinely measured in clinical conditions other than leukaemia or transplantation immunology $[6,7]$. Considering uNK cells, there have been mainly two different suggestions on references ranges, differing in the used technique of NK cell analysis. Our group focused on the number of uNK cells per $\mathrm{mm}^{2}$ and regarded $>300 \mathrm{uNK}$ cells per $\mathrm{mm}^{2}$ as elevated, whereas Chen et al. focused on the percentage of total stroma cells and considered $4.5 \%$ as the upper limit of the reference range $[8,9]$.

UNK cells play an important role in trophoblast invasion and angiogenesis and represent about $70 \%$ of immune cells at the feto-maternal interface [10]. The exact mechanism how alterations of NK cells interfere with the development of a successful pregnancy is still a matter of debate $[7,11]$. In vitro studies on vessel models have shown uNK cells leading to a disruption of vascular smooth muscle cells, which might lead to an altered spiral artery remodeling and contribute to pregnancy complications such as RM $[12,13]$. In an animal model, mice lacking uNK cells, spiral artery remodeling was impaired, but was restored by transplantation of bone marrow from donors (with reconstitution of NK cells) [14-16]. Altered levels of NK cells were reported in peripheral blood, endometrium and the decidua of RM patients $[4,5]$. Increased uNK cells in RM patients were described in several studies [17-19], although others could not support these findings [20, 21]. Conflicting results have also been described for pNK cells in RM patients [22, 23]. Analysing $n=85$ RM patients and $n=27$ controls by flow cytometry (FACS), Wang et al. did not find significant differences in pNK cell numbers [23]. In contrast, a later study reported significant higher pNK cell percentages in RM patients $(n=104)$ compared to controls $(n=33)$ [22].

A higher pNK cell number in RM patients $(n=210)$ compared to controls $(n=45)$ has been found in a retrospective study, whereas no difference in pNK cell numbers between pRM $(n=145)$ and sRM $(n=65)$ was evident [24]. In another study, a higher proportion and concentration of pNK cells in pRM compared to sRM patients was demonstrated [25]. When compared to controls, sRM patients showed higher pNK cells (absolute numbers and percentages), but the difference did not reach significance [25]. No significant differences were present with regard to uNK cells in pRM versus sRM in a small study group (pRM vs sRM: $n=11$ vs $n=9$ ) [21].

Recently, we demonstrated higher absolute pNK cells, but no differences in uNK cell levels in patients with pRM compared to sRM [1]. However, due to the limited sample size of $n=151 \mathrm{pRM}$ and $n=85$ sRM patients, the study was underpowered to analyse subgroups of idiopathic RM (iRM) patients. Regarding uNK cells, we were able to show elevated uNK cells in iRM patients compared to fertile controls [1].

While several studies have proposed a different immune regulation in pRM and sRM patients, sample sizes were too small to reveal differences in pNK as well as uNK cells after ruling out all established risk factors. To further delineate possibly different immunoregulatory processes between idiopathic pRM (ipRM) and sRM (isRM) patients, we analysed pNK and uNK cells in a well-defined, large cohort of RM patients in a prospective study.

\section{Material and methods \\ Study population}

Within our outpatient clinic $n=773$ couples with RM were recruited between March 2012 and October 2018. Non-pregnant RM patients were routinely screened (RM screening test) for (i) anatomical disorders by vaginal ultrasound and office hysteroscopy; (ii) endocrine dysfunctions [polycystic ovary syndrome according to Rotterdam criteria [26], hyperprolactinemia, hyperandrogenaemia, insufficiency of the corpus luteum and thyroidal dysfunctions (hypo-/ hyperthyroidism, thyroid autoantibodies)]; (iii) autoimmune disorders (antinuclear antibodies $>1: 160$, anticardiolipin antibodies ( $\operatorname{IgG} \geq 10 \mathrm{U} / \mathrm{ml}, \operatorname{IgM} \geq 5 \mathrm{U} / \mathrm{ml}$ ), anti- $\beta 2$-glycoprotein (IgG $\geq 10 \mathrm{U} / \mathrm{ml}, \operatorname{IgM} \geq 10 \mathrm{U} / \mathrm{ml}$ ), or lupus anticoagulant); (iv) deficiencies in coagulation factors (protein C, protein S, factor XII, or antithrombin); (v) inherited thrombophilia (mutations in the factor $\mathrm{V}$ or prothrombin gene) and (vi) parental chromosomal disorders (structural aberrations). Analyses were performed at least 3 months after the last pregnancy.

We identified $n=575$ couples with $\geq 3$ consecutive RM. Subgroups consisted of $n=393$ primary RM (pRM, women who had no live births), $n=182$ secondary RM (sRM, women who had one or more previous live births followed by $\geq 3$ consecutive RM). After routine screening for the above-mentioned risk factors, $n=248$ idiopathic RM (iRM) were identified, including $n=167$ primary iRM (ipRM) and $n=81$ secondary iRM (isRM) patients.

Diagnostics were performed in the mid-luteal phase of the menstrual cycle between day 7 and day 10 after the 
mid-cycle LH (luteinizing hormone) surge. Patients were advised to measure LH surge at home. Age, gravidity, body mass index (BMI), period of time since miscarriage (months), progesterone $(\mathrm{ng} / \mathrm{ml})$, thyroid-stimulating hormone (TSH, mU/l), antinuclear and thyroid autoantibodies (TPO (thyroid peroxidase antibody), thyroglobulin antibody (TG)) were evaluated as potential variables influencing NK cell number. Differences between pNK cells (per $\mu \mathrm{l}$ and percentages), uNK cells (absolute numbers per $\mathrm{mm}^{2}$ ) and correlations of these cells between the RM and iRM subgroups were defined as primary outcome measures. The analysis of variables (immune and clinical parameters) influencing pNK and uNK cells were secondary outcome measures. Characteristics of RM patients and subgroups are shown in Table 1. Signed informed consent was obtained from all participants, allowing analysis of all clinical and laboratory data mentioned in this paper.

\section{Ethical approval}

The Human Investigation Review Board of the RuprechtKarls University Heidelberg approved the study (S-428/ 2009).

\section{Analysis of peripheral lymphocyte subpopulations}

Peripheral blood levels of $\mathrm{CD} 45^{+} \mathrm{CD}^{-} \mathrm{CD} 56^{+} \mathrm{CD} 16^{+} \mathrm{NK}$ cells were determined using four-color FACS. IgG2a/ fluorescein isothiocyanate, IgG2a/phycoerythrin, IgG2a/ allophycocyanin, and IgG2a/peridinin-chlorophyll-protein complex antibodies served as isotype controls. All antibodies were purchased from Becton Dickinson (BD)/ Pharmingen (Heidelberg, Germany; BD Multitest CD3/ CD16 + 56/CD45/CD19, catalogue number 342446;). Ten microliters $(\mu \mathrm{L})$ of a mixture of four different monoclonal antibodies conjugated with fluorescein isothiocyanate, phycoerythrin, allophycocyanin or peridinin-chlorophyllprotein complex were added to $50 \mu \mathrm{L}$ of heparinized whole blood and incubated for $15 \mathrm{~min}$ at room temperature. Erythrocytes were lysed with $\mathrm{NH}_{4} \mathrm{Cl}$ for 15 min. The FACS was calibrated before each run using CaliBRITE beads (BD Pharmingen, Heidelberg, Germany) to ensure optimal counting.

\section{Detection of uterine natural killer cells}

A uterine biopsy was taken in $n=346$ patients in the midluteal phase using a Pipelle sampler (Pipelle ${ }^{\circ} \mathrm{CCD}$, Laboratoire CCD, Paris, France) to evaluate uterine $\mathrm{CD}^{+} 6^{+} \mathrm{NK}$ cells by immunohistochemistry. All endometrial biopsies were fixed in $5 \%$ buffered formalin for at least $24 \mathrm{~h}$ and embedded in paraffin. The samples were cut at $4 \mu \mathrm{m}$, mounted on SuperFrost/Plus slides (Menzel, Germany) and deparaffinized and rehydrated. Antibodies were diluted with Background Reducing Components (DAKO, Germany). Antigen retrieval was accomplished by using citrate buffer. To inhibit endogenous peroxidase activity, samples were incubated with Peroxidase Block (DAKO, Germany) for $7 \mathrm{~min}$ as recommended and washed in TBSTween20 (0.05\%; TBS, pH 7.6). Samples were incubated with the primary mouse anti-human CD56 antibody

Table 1 Characteristics of RM patients

\begin{tabular}{|c|c|c|c|c|}
\hline & $\mathrm{RM}(n=575)$ & $\operatorname{pRM}(n=393)$ & $\operatorname{sRM}(n=182)$ & $p$-value \\
\hline $\mathrm{Age}^{\mathrm{a}}$ & $34.5 \pm 4.5$ & $34.1 \pm 4.7$ & $35.3 \pm 3.8$ & 0.0037 \\
\hline Gravidity $^{\mathrm{b}}$ & $4(3 / 15)$ & $3(3 / 14)$ & $3(3 / 15)$ & $<0.001$ \\
\hline Parity $^{\mathrm{b}}$ & $0(0 / 4)$ & 0 & $1(1 / 4)$ & $<0.001$ \\
\hline No. of miscarriages ${ }^{b}$ & $3(3 / 14)$ & $3(3 / 14)$ & $3(3 / 14)$ & 0.68 \\
\hline Time since last miscarriage $\mathrm{e}^{a}$ & $6.8 \pm 8.9$ & $5.7 \pm 5.1$ & $6.0 \pm 5.5$ & 0.42 \\
\hline $\mathrm{BMl}^{\mathrm{a}}$ & $24.3 \pm 4.2$ & $23.98 \pm 4.1$ & $24.82 \pm 4.4$ & 0.135 \\
\hline \multirow[t]{2}{*}{$P 4^{\mathrm{a}}$} & $10.6 \pm 5.7$ & $10.7 \pm 5.6$ & $10.3 \pm 5.8$ & 0.50 \\
\hline & $\operatorname{iRM}(n=248)$ & ipRM $(n=167)$ & isRM $(n=81)$ & $p$-value \\
\hline $\mathrm{Age}^{\mathrm{a}}$ & $34.2 \pm 4.9$ & $33.6 \pm 5.1$ & $35.3 \pm 4.2$ & 0.0097 \\
\hline Gravidity $^{\mathrm{b}}$ & $4(4 / 15)$ & $3(3 / 10)$ & $4(4 / 15)$ & $<0.001$ \\
\hline Parity $^{\mathrm{b}}$ & $0(0 / 4)$ & 0 & $1(1 / 4)$ & $<0.001$ \\
\hline No. of miscarriages ${ }^{b}$ & $3(3 / 14)$ & $3(3 / 10)$ & $3(3 / 14)$ & 0.89 \\
\hline Time since last miscarriage ${ }^{a}$ & $6.1 \pm 6.6$ & $6.2 \pm 7.3$ & $5.8 \pm 5.1$ & 0.67 \\
\hline$B M l^{\mathrm{a}}$ & $24.12 \pm 4.5$ & $23.25 \pm 3.9$ & $25.4 \pm 5.1$ & 0.029 \\
\hline$P 4^{\mathrm{a}}$ & $11.1 \pm 6.0$ & $11.1 \pm 6.2$ & $11.0 \pm 5.7$ & 0.90 \\
\hline
\end{tabular}

${ }^{a}$ mean \pm SD

${ }^{\mathrm{b}}$ median (min/max)

Characteristics: Age (years), Gravidity, Parity, No. of miscarriages (number of miscarriages), Time since last miscarriage (at least 3 months), BMI (body mass index), P4 (progesterone levels, $\mathrm{ng} / \mathrm{ml}$ ) at time of immune diagnostics (luteal phase of the menstrual cycle); $R M$ recurrent miscarriage, $p R M$ primary RM, $s R M$ secondary $\mathrm{RM}$, iRM idiopathic RM, ipRM idiopathic primary RM, isRM idiopathic secondaryRM 
(clone:123C3, isotype: IgG1, DAKO, Germany, catalogue number: M730401-2, concentration: $305 \mathrm{mg} / \mathrm{l}$, used with 1:100) for $1 \mathrm{~h}$ and for $30 \mathrm{~min}$ with the secondary antibody (labelled polymer-HRP anti-mouse, clone: DAKGO1, isotype: IgG1, DAKO, Germany, catalogue number: K800021-1) at room temperature. Between each step, all samples were washed profusely with TBS-Tween 20 $(0.05 \%)$. The peroxidase reaction was achieved with $\mathrm{DAB}$ (3.3'-diaminobenzidine; DAKO, Germany) and discontinued with water after $15 \mathrm{~min}$. Haematoxylin staining was followed by mounting the cover slide with Histofluid (Marienfeld, Germany). All samples were analysed independently by two experienced biologists/physicians using a Zeiss AxioPlan Microscope and the AxioVison 4.8 program. $\mathrm{CD}^{+} 6^{+}$uNK cells were evaluated as absolute numbers per $\mathrm{mm}^{2}$.

\section{Statistics}

Statistical analysis was performed using GraphPad Prism (version 7.00 for Windows, GraphPad Software, La Jolla California USA, www.graphpad.com).

In case of normally distributed raw data, student's t-test was used to compare two groups and one-way ANOVA was used for comparison of more than two groups, followed by Holm-Sidak's multiple comparison test. Otherwise, Kruskal-Wallis for non-parametric testing was used to compare groups followed by Dunn's multiple comparison test. Correlations between parameters were calculated by means of Pearson's correlations coefficient, since the analysed data were ratio-scaled. Data of dichotomous variables were compared by Chi-square test. A $p$ value $<0.05$ was considered significant.

\section{Results}

\section{Study population}

Characteristics of RM patients are displayed in detail in Table 1. Number of miscarriages, time passed after the last miscarriage and luteal phase progesterone levels did not differ between the subgroups of RM patients. Patients with isRM had a significant higher BMI than patients with ipRM. Mean age, gravidity and parity of patients were significantly higher in sRM and isRM versus pRM and ipRM patients respectively.

\section{Peripheral natural killer cells}

Peripheral $\mathrm{CD} 45^{+} \mathrm{CD} 3^{-} \mathrm{CD} 56^{+} \mathrm{CD} 16^{+} \mathrm{NK}$ cells of RM patients are shown in Table 2. As shown in Fig. 1a and b, the distribution of NK cell numbers and percentages is widespread. Compared to patients with sRM, women with $\mathrm{pRM}$ showed higher $\mathrm{pNK}$ absolute numbers and percentages (Table 2; Fig. 1a). These differences were also present in idiopathic RM patients in the corresponding subgroups (Table 2, Fig. 1b). No significant difference was observed when comparing patients with ipRM vs non-ipRM and isRM vs non-isRM.

\section{Uterine natural killer cells}

Numbers of $\mathrm{CD}^{2} 6^{+}$uNK cells/ $\mathrm{mm}^{2}$ in the different RM subgroups are shown in Table 2. There was no significant difference of uNK cells between patients with pRM and sRM. However, when focusing on idiopathic RM, patients with isRM showed significantly higher uNK cell levels $/ \mathrm{mm}^{2}$ compared to patients with ipRM (Table 2; Fig. 2). Further, patients with isRM showed higher uNK cells than patients with non-isRM $(288.4 \pm 239.3$ vs $180.9 \pm 127.1, p=0.007)$. No significant difference of uNK cells was detected between ipRM and non-ipRM. When put into categories of potential reference ranges that have been proposed in a previous study [9], highly elevated uNK cells $\left(>600 / \mathrm{mm}^{2}\right)$ were more present in patients with isRM compared to patients with ipRM patients $(p=0.04$, Table 3$)$.

\section{Correlation between uterine and peripheral NK cells}

We find a moderate positive correlation between $\mathrm{CD} 56^{+}$ uNK cells and $\mathrm{CD} 45^{+} \mathrm{CD} 3^{-} \mathrm{CD} 56^{+} \mathrm{CD} 16^{+}$pNK cells only in ipRM patients $(/ \mu \mathrm{l}: \mathrm{r}=0.393, n=102, p<0.001$; percentages: $r=0.331, n=102, p<0.001)$. In contrast, a weak negative correlation was detected between $\mathrm{CD}^{2} 6^{+} \mathrm{uNK}$

Table $2 \mathrm{CD} 5^{+} \mathrm{CD}^{-} \mathrm{CD}^{+} 6^{+} \mathrm{CD} 16^{+}$pNK cells and $\mathrm{CD}_{5} 6^{+}$uNK cells in RM patients

\begin{tabular}{|c|c|c|c|c|c|}
\hline & & $\mathrm{RM}(n=575)$ & $\mathrm{pRM}(n=393)$ & $\operatorname{sRM}(n=182)$ & $p$-value \\
\hline \multirow{2}{*}{$\begin{array}{c}\mathrm{CD} 45^{+} \mathrm{CD} 3^{-} \mathrm{CD} 56^{+} \mathrm{CD} 16^{+} \\
\text {pNK cells }\end{array}$} & Percentages (mean $\pm \mathrm{SD}$ ) & $12.0 \pm 5.3$ & $12.4 \pm 5.5$ & $11.1 \pm 4.6$ & 0.0043 \\
\hline & Absolute numbers (mean \pm SD) & $228.3 \pm 116.4$ & $239.1 \pm 118.7$ & $205.1 \pm 107.9$ & 0.0011 \\
\hline \multirow[t]{2}{*}{$\mathrm{CD} 6^{+}$uNK cells } & Absolute numbers (mean $\pm \mathrm{SD}$ ) & $215.2 \pm 180.3(n=346)^{a}$ & $205.4 \pm 170.2(n=245)^{a}$ & $238.8 \pm 201.6(n=101)^{a}$ & 0.12 \\
\hline & & $\mathrm{iRM}(n=248)$ & $\operatorname{ipRM}(n=167)$ & isRM $(n=81)$ & $p$-value \\
\hline \multirow{2}{*}{$\begin{array}{c}\mathrm{CD} 45^{+} \mathrm{CD}^{-}{ }^{-} \mathrm{CD} 56^{+} \mathrm{CD}^{-} 6^{+} \\
\text {pNK cells }\end{array}$} & Percentages (mean \pm SD & $12.2 \pm 5.1$ & $12.8 \pm 5.4$ & $11.1 \pm 4.3$ & 0.0181 \\
\hline & Absolute numbers (mean \pm SD) & $232.2 \pm 111.9$ & $244.9 \pm 112.9$ & $206.0 \pm 105.6$ & 0.0099 \\
\hline $\mathrm{CD} 6^{+}$uNK cells & Absolute numbers (mean \pm SD) & $242.5 \pm 207.1(n=156)^{\mathrm{a}}$ & $218.2 \pm 184.5(n=102)^{\mathrm{a}}$ & $288.4 \pm 239.3(n=54)^{\mathrm{a}}$ & 0.044 \\
\hline
\end{tabular}

$R M=$ recurrent miscarriage, $p R M=$ primary $\mathrm{RM}, s R M=$ secondary $\mathrm{RM}, i R M=$ idiopathic $\mathrm{RM}, i p R M=$ idiopathic primary $\mathrm{RM}$, is $R M=$ idiopathic secondary $\mathrm{RM}$.

andicates the number of patients in which a uterine biopsy was obtained 

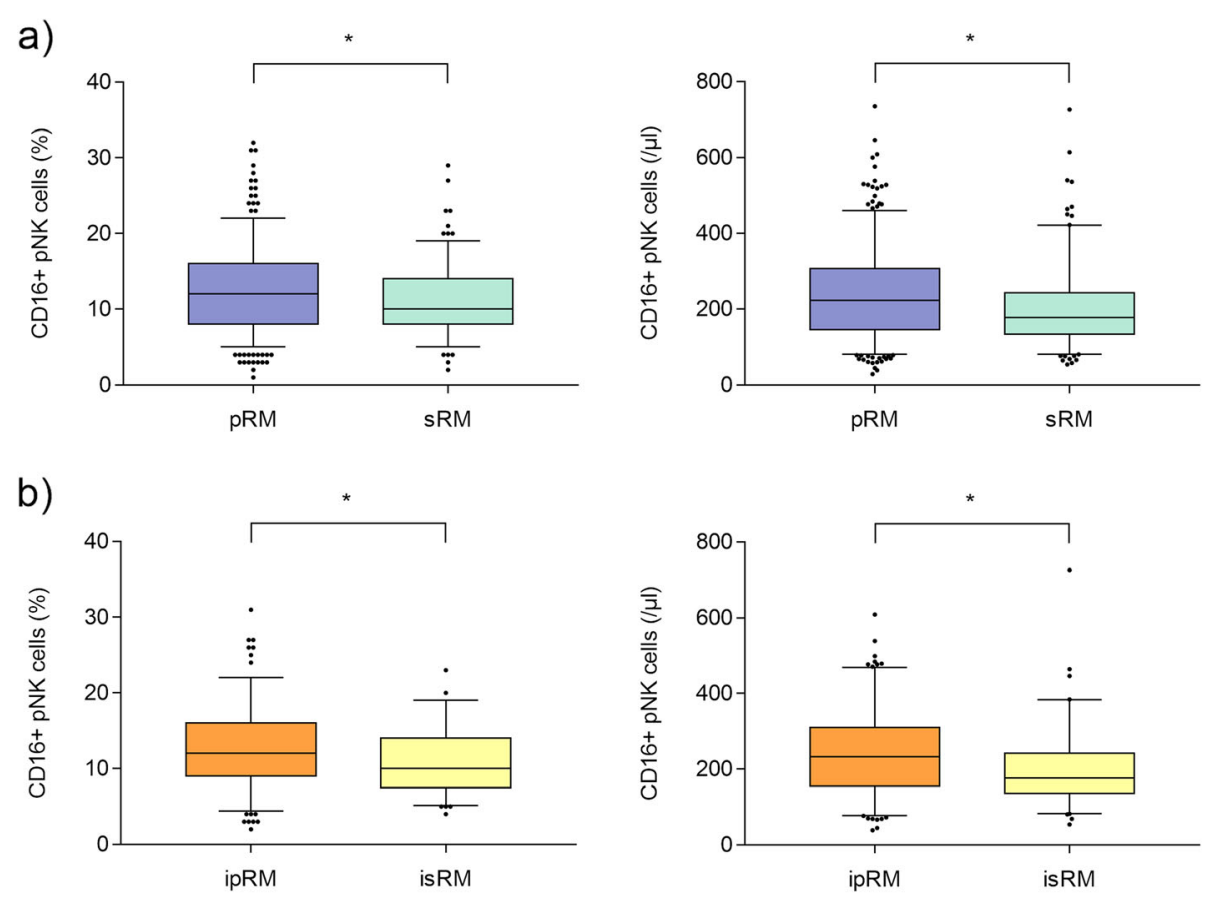

Fig. $1 \mathrm{CD} 45^{+} \mathrm{CD}^{-} \mathrm{CD} 56^{+} \mathrm{CD} 16^{+} \mathrm{pNK}$ cells (percentages and absolute numbers) in RM (a) and iRM (b) patients. $\mathrm{CD}^{2} 5^{+} \mathrm{CD} 3^{-} \mathrm{CD} 16^{+} \mathrm{CD} 56^{+} \mathrm{pNK}$ cells were significantly higher in (i) pRM than (i) SRM patients (percentages and absolute numbers $/ \mu$ l). Whiskers show 5 and $95 \%$ percentiles, $p<0.05$ was considered significant, (i) pRM = (idiopathic) primary recurrent miscarriage, (i) sRM = (idiopathic) secondary recurrent miscarriage

cells and absolute numbers of $\mathrm{CD} 45^{+} \mathrm{CD} 3^{-} \mathrm{CD} 56^{+} \mathrm{CD} 16^{+}$ pNK cells in isRM patients $(r=0.301, n=54, p=0.027)$.

\section{Discussion}

Due to the various established risk factors, study populations of patients with RM are characterized by a distinct heterogeneity. Finding and describing new aspects of immune regulation on the one hand and confirming results from studies with smaller sample size in large populations on the other hand will lead to a better understanding of the pathophysiology of RM.

Higher absolute numbers but not percentages of pNK cells were detected in $n=151$ patients with pRM compared to $n=85$ patients with sRM [1]. Within the current study the distribution of pNK cell numbers (absolute and percentages) was widespread, which was also shown in other studies analysing lymphocytes by FACS [6]. Still, both absolute numbers as well as percentages of pNK cells were significantly higher in patients with pRM compared to sRM, confirming the findings of our previous study [1]. Higher activity of pNK cells was shown in pRM compared to sRM patients in a study by Shakar et al. [25], underlining a possible impact of previous live births on NK cells in sRM patients.

Due to their different phenotype and the missing detection of a correlation between pNK and uNK cells, we and

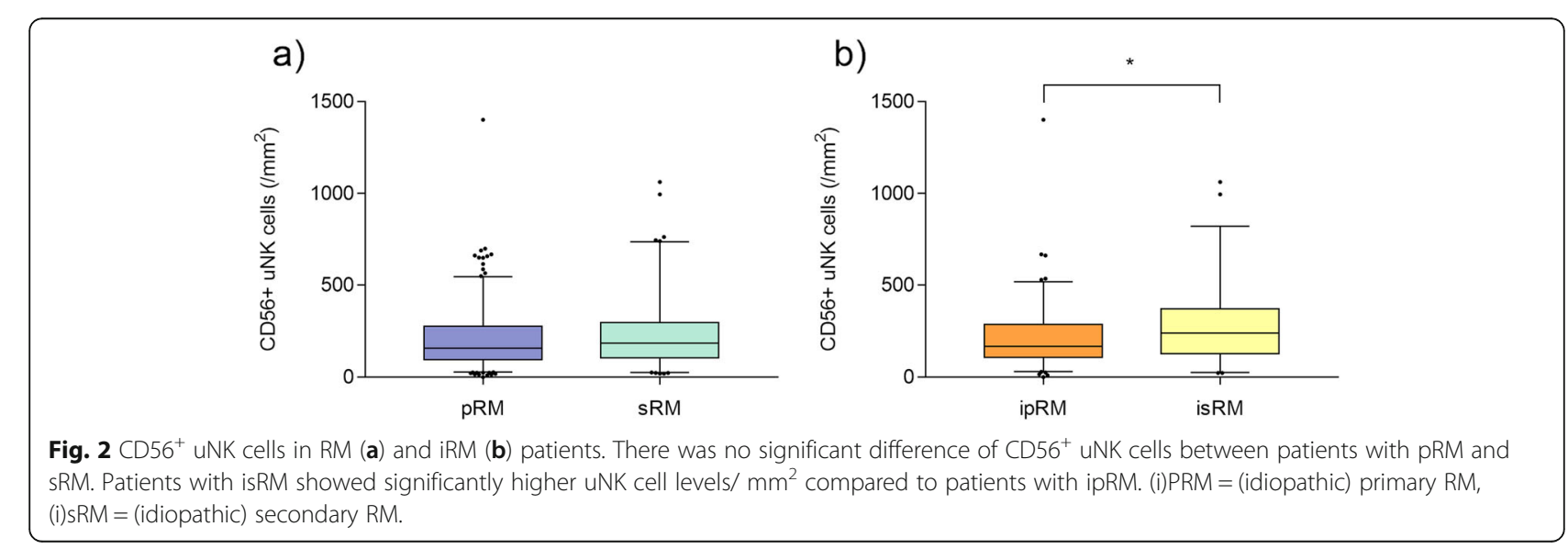


Table $3 \mathrm{CD}^{2} 6^{+}$uNK cells in RM patients - Number of patients within previously proposed reference ranges (9)

\begin{tabular}{|c|c|c|c|c|}
\hline \multirow[t]{2}{*}{ Range of CD56 ${ }^{+}$uNK cells } & \multicolumn{4}{|c|}{ Number (percentage) of patients within range } \\
\hline & $\mathrm{RM}(n=346)$ & $\operatorname{pRM}(n=245)$ & $\operatorname{sRM}(n=101)$ & $p$-value \\
\hline$<40$ & $29(8.38)$ & $22(8.98)$ & $7(6.93)$ & 0.53 \\
\hline$\geq 40<300$ & $238(68.78)$ & $169(68.98)$ & $69(68.32)$ & 0.90 \\
\hline$\geq 300$ & $79(22.83)$ & $54(22.04)$ & $25(24.8)$ & 0.58 \\
\hline \multirow[t]{2}{*}{$>600$} & $15(4.335)$ & $9(3.67)$ & $6(5.94)$ & 0.30 \\
\hline & $\operatorname{iRM}(n=156)$ & ipRM $(n=102)$ & isRM $(n=54)$ & $p$-value \\
\hline$<40$ & $12(7.69)$ & $8(7.84)$ & $4(7.41)$ & 0.92 \\
\hline$\geq 40<300$ & $102(65.39)$ & $70(68.63)$ & $32(59.26)$ & 0.24 \\
\hline$\geq 300$ & $42(26.92)$ & $24(23.53)$ & $18(33.33)$ & 0.18 \\
\hline$>600$ & $9(5.77)$ & $3(2.94)$ & $6(11.11)$ & 0.04 \\
\hline
\end{tabular}

$R M$ recurrent miscarriage, $p R M$ primary $\mathrm{RM}, S R M$ secondary RM, iRM idiopathic $\mathrm{RM}$, ipRM idiopathic primary RM, isRM idiopathic secondary RM.

others have suggested categorizing these lymphocytes as two independent immune markers for RM [1, 27]. Basic science has shown the essential role of uNK cells in successful development of the placenta, e.g. the involvement in the remodelling of the spiral arteries [12, 28, 29]. Elevations of uNK cells have been associated with hypertensive disorders of pregnancy, preeclampsia and fetal growth restriction [30-32]. Significantly higher uNK cell numbers have previously been described in patients with iRM $(\geq 3$ consecutive clinical miscarriages) compared to fertile controls [9]. Yet, there has been no international consensus on the standardization of uNK cell testing in RM patients. Consequently, reference ranges of low, normal and elevated uNK cells need to be established. Considering the reference ranges proposed by our group and by Chen et al., $34.5 \%$ respectively $22 \%$ of iRM patients showed elevated uNK cells and $3 \%$ respectively $16 \%$ of iRM patients low uNK cells $[8,9]$. However, these two studies did not show differences between patients with ipRM and isRM. Our current study shows no significant difference in low, normal and elevated uNK cells between ipRM and isRM either. However, absolute uNK cells $/ \mathrm{mm}^{2}$ as well as the fraction of highly elevated UNK cells (defined as $>600$ uNK cells $/ \mathrm{mm}^{2}$ ) are significantly higher in patients with isRM compared to ipRM (both $p=0.04$ ), stressing the need to investigate subpopulations and the impact of a previous live birth. A previous study on uterine NK cells comparing patients with primary versus secondary infertility has proposed a different immune regulation, showing higher uNK cells in secondary infertility patients [33].

We hypothesize that differences of pNK and uNK cells between pRM and sRM reflect an interaction with fetal microchimeric cells. The mechanism of feto-maternal microchimerism describes the bidirectional traffic of cells across the placenta resulting in an antigenic challenge [34]. This process starts as early as 7 weeks of gestation and therefore also in patients with pRM [35]. However, feto-maternal microchimerism reaches a maximum at delivery, which only occurs in patients with sRM [35]. Obstetric and neonatal complications are associated with an increased transfer of fetal cells into maternal circulation [36-39] and an increased production of inflammatory cytokines in the peripheral blood and endometrium [4042]. Studies have shown a higher rate of gestational complications in sRM during their first pregnancy and delivery, indicating an increased transfer of fetal cells [43, 44]. These cells, persisting for up to 27 years, might induce a chronic immune stimulation, resulting in a disturbed immune regulation in the mother with lower absolute numbers and percentages of pNK cells [45]. This hypothesis is in line with the results of previous studies showing a decrease in pNK cells and NK cell cytotoxicity during pregnancy and postpartum, which might be a maternal response to fetal microchimeric cells $[46,47]$. As feto-maternal microchimerism is a physiological process, RM patients might fail to adapt adequately to the challenge the microchimeric cells oppose on the maternal immune system causing a different immune reaction towards the newly implanting embryo with lower $\mathrm{pNK}$ and higher uNK cells in sRM patients.

Of note, the (i) pRM and (i) sRM groups in our study showed significant differences in age and BMI, which might confound our findings. A study of our group showed no influence of clinical parameters like BMI, age, time of last miscarriage or progesterone levels on pNK and uNK cell numbers [1]. Furthermore, the influence of body weight and age on lymphocyte counts is discussed controversially and studies did not compare slight differences in BMI and age like in our study population [48-50]. As described before, this study was not designed to study differences in pRM or sRM in comparison to controls. To study these differences, one would have to study two groups: controls that have already had a live birth and controls that never had a live 
birth. In general, the most appropriate control group for RM has yet to be defined.

\section{Conclusion}

The interaction between pNK and uNK cells is a matter of debate [1,51] and so far, no direct correlation has been shown in studies. In our large, well defined cohort of women with RM, allowing for discrimination between patients with pRM and sRM, we are the first to show a positive correlation of pNK and uNK cells in patients with ipRM. Interestingly, patients with isRM show higher uNK cells, but lower pNK cells compared to women with ipRM, indicating a possible abnormal recruitment of NK cells from peripheral blood to the endometrium. In conclusion, this study indicates that there might be a different profile of NK cells between patients with pRM and sRM. These immune alterations in $\mathrm{pRM}$ and sRM could contribute to a different aetiology of RM. As some findings are only evident in iRM patients, it stresses the need to exclude established risk factors for RM before immune markers like NK cells are investigated in the peripheral blood and endometrium. Due to the overlap of the distribution of NK cell results in RM patients, further studies focusing on the function of pNK and uNK cells are needed in order to clearly identify RM patients with distinct immune abnormalities. The clinical relevance should be interpreted with caution until specificity and sensitivity of these markers are further evaluated.

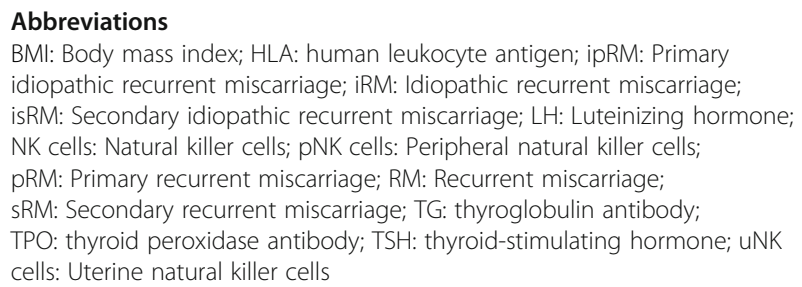
idiopathic recurrent miscarriage; iRM: Idiopathic recurrent miscarriage; isRM: Secondary idiopathic recurrent miscarriage; LH: Luteinizing hormone; NK cells: Natural killer cells; pNK cells: Peripheral natural killer cells; pRM: Primary recurrent miscarriage; RM: Recurrent miscarriage; sRM: Secondary recurrent miscarriage; TG: thyroglobulin antibody; TPO: thyroid peroxidase antibody; TSH: thyroid-stimulating hormone; uNK cells: Uterine natural killer cells

\section{Acknowledgements}

We would like to acknowledge the skilful technical assistance of Maja Weber, Martina Kutsche-Bauer, Regina Seemuth, Marita Heilke, Anja Brüchig, Silja Petersen und Lisa Michel.

\section{Authors'contributions}

$\mathrm{KV}$ : performed the literature search and contributed towards the data extraction, the analyses and interpretation of the data and the drafting of the manuscript. BT: planned the idea for the study, constructed the protocol, contributed towards the literature search and the analyses and interpretation of the data, and revised the manuscript for important intellectual content. RJK: planned the idea for the study, constructed the protocol, and contributed towards the data extraction, the analyses and interpretation of the data and the drafting of the manuscript.BB: contributed towards the drafting of the manuscript. RT, HH, VD and TS: contributed towards the drafting and revision of the manuscript for important intellectual content. BT and KV contributed equally to this manuscript. All authors approved the final version of the manuscript.

\section{Funding}

No financial support was received for this study.

\section{Availability of data and materials}

The datasets used and/or analysed during the current study are available from the corresponding author on reasonable request.

Ethics approval and consent to participate

The Human Investigation Review Board of the Ruprecht-Karls University Heidelberg approved the study (S-428/2009).

\section{Consent for publication}

Not applicable

\section{Competing interests}

BT and RJK are shareholders of Reprognostics GbR. KV, RT, BB, HH, TS and VD declare no conflict of interest.

\section{Author details}

'Department of Gynecological Endocrinology and Reproductive Medicine, Medical University Innsbruck, Anichstrasse 35, 6020 Innsbruck, Austria. ${ }^{2}$ Department of Gynecological Endocrinology and Fertility Disorders, Ruprecht-Karls University Heidelberg, Im Neuenheimer Feld 440, 69120 Heidelberg, Germany. ${ }^{3}$ Department of Neonatology, Heidelberg University Children's Hospital, Im Neuenheimer Feld 430, 69120 Heidelberg, Germany. ${ }^{4}$ Transplantation-Immunology, Institute of Immunology, Ruprecht-Karls University Heidelberg, Im Neuenheimer Feld 672, 69120 Heidelberg, Germany.

Received: 15 April 2019 Accepted: 16 August 2019

Published online: 31 August 2019

\section{References}

1. Kuon RJ, Vomstein K, Weber M, Muller F, Seitz C, Wallwiener S, et al. The "killer cell story" in recurrent miscarriage: association between activated peripheral lymphocytes and uterine natural killer cells. J Reprod Immunol. 2017;119:9-14.

2. Christiansen $\mathrm{OB}$. A fresh look at the causes and treatments of recurrent miscarriage, especially its immunological aspects. Hum Reprod Update. 1996;2(4):271-93.

3. Robertson MJ, Ritz J. Biology and clinical relevance of human natural killer cells. Blood. 1990;76(12):2421-38.

4. Seshadri S, Sunkara SK. Natural killer cells in female infertility and recurrent miscarriage: a systematic review and meta-analysis. Hum Reprod Update. 2014;20(3):429-38.

5. Tang AW, Alfirevic Z, Quenby S. Natural killer cells and pregnancy outcomes in women with recurrent miscarriage and infertility: a systematic review. Hum reprod (Oxford). 2011;26(8):1971-80.

6. Bisset LR, Lung TL, Kaelin M, Ludwig E, Dubs RW. Reference values for peripheral blood lymphocyte phenotypes applicable to the healthy adult population in Switzerland. Eur J Haematol. 2004;72(3):203-12.

7. Moffett A, Shreeve N. First do no harm: uterine natural killer (NK) cells in assisted reproduction. Hum reprod (Oxford). 2015;30(7):1519-25.

8. Kuon RJ, Weber M, Heger J, Santillan I, Vomstein K, Bar C, et al. Uterine natural killer cells in patients with idiopathic recurrent miscarriage. Am J Reprod Immunol. 2017;78:e12721. https://doi.org/1 $0.1111 /$ aji.12721.

9. Chen X, Mariee N, Jiang L, Liu Y, Wang CC, Li TC, et al. Measurement of uterine natural killer cell percentage in the periimplantation endometrium from fertile women and women with recurrent reproductive failure: establishment of a reference range. Am J Obstet Gynecol. 2017;217(6):680 e1-6.

10. Lash GE, Bulmer JN. Do uterine natural killer (uNK) cells contribute to female reproductive disorders? J Reprod Immunol. 2011;88(2):156-64.

11. Sacks $\mathrm{G}$. Enough! Stop the arguments and get on with the science of natural killer cell testing. Hum reprod (Oxford). 2015;30(7):1526-31.

12. Robson A, Harris LK, Innes BA, Lash GE, Aljunaidy MM, Aplin JD, et al. Uterine natural killer cells initiate spiral artery remodeling in human pregnancy. FASEB J. 2012;26(12):4876-85.

13. Robson A, Lash GE, Innes BA, Zhang JY, Robson SC, Bulmer JN. Uterine spiral artery muscle dedifferentiation. Hum reprod (Oxford). 2019;34(8):142838. https://doi.org/10.1093/humrep/dez124

14. Guimond MJ, Wang B, Croy BA. Engraftment of bone marrow from severe combined immunodeficient (SCID) mice reverses the reproductive deficits 
in natural killer cell-deficient tg epsilon 26 mice. J Exp Med. 1998;187(2): 217-23.

15. Smith $S D$, Dunk CE, Aplin JD, Harris LK, Jones RL. Evidence for immune cell involvement in decidual spiral arteriole remodeling in early human pregnancy. Am J Pathol. 2009;174(5):1959-71.

16. Greenwood JD, Minhas K, di Santo JP, Makita M, Kiso Y, Croy BA. Ultrastructural studies of implantation sites from mice deficient in uterine natural killer cells. Placenta. 2000;21(7):693-702.

17. Quenby S, Kalumbi C, Bates M, Farquharson R, Vince G. Prednisolone reduces preconceptual endometrial natural killer cells in women with recurrent miscarriage. Fertil Steril. 2005;84(4):980-4.

18. Clifford $K$, Flanagan AM, Regan L. Endometrial CD56+ natural killer cells in women with recurrent miscarriage: a histomorphometric study. Hum reprod. (Oxford). 1999;14(11):2727-30.

19. Tuckerman E, Laird SM, Prakash A, Li TC. Prognostic value of the measurement of uterine natural killer cells in the endometrium of women with recurrent miscarriage. Human reproduction (Oxford, England). 2007; 22(8):2208-13.

20. Michimata T, Ogasawara MS, Tsuda H, Suzumori K, Aoki K, Sakai M, et al. Distributions of endometrial NK cells, B cells, T cells, and Th2/Tc2 cells fail to predict pregnancy outcome following recurrent abortion. Am J Reprod Immunol. 2002;47(4):196-202.

21. Lachapelle MH, Miron P, Hemmings R, Roy DC. Endometrial T, B, and NK cells in patients with recurrent spontaneous abortion. Altered profile and pregnancy outcome. J Immunol. 1996;156(10):4027-34.

22. King K, Smith S, Chapman M, Sacks G. Detailed analysis of peripheral blood natural killer (NK) cells in women with recurrent miscarriage. Hum Reprod Oxford. 2010;25(1):52-8.

23. Wang Q, Li TC, Wu YP, Cocksedge KA, Fu YS, Kong QY, et al. Reappraisal of peripheral NK cells in women with recurrent miscarriage. Reprod BioMed Online. 2008;17(6):814-9.

24. Triggianese $\mathrm{P}$, Perricone $\mathrm{C}$, Conigliaro $\mathrm{P}$, Chimenti MS, Perricone R, De Carolis C. Peripheral blood natural killer cells and mild thyroid abnormalities in women with reproductive failure. Int J Immunopathol Pharmacol. 2016; 29(1):65-75

25. Shakhar K, Ben-Eliyahu S, Loewenthal R, Rosenne E, Carp H. Differences in number and activity of peripheral natural killer cells in primary versus secondary recurrent miscarriage. Fertil Steril. 2003;80(2):368-75.

26. The Rotterdam ESHRE/ASRM-Sponsored PCOS Consensus Workshop Group, Revised 2003 consensus on diagnostic criteria and longterm health risks related to polycystic ovary syndrome. Fertil Steril. 2004;81(1):19-25.

27. Moffett A, Colucci F. Uterine NK cells: active regulators at the maternal-fetal interface. J Clin Invest. 2014;124(5):1872-9.

28. Tessier DR, Yockell-Lelievre J, Gruslin A. Uterine spiral artery remodeling: the role of uterine natural killer cells and Extravillous trophoblasts in Normal and high-risk human pregnancies. Am J Reprod Immunol. 2015;74(1):1-11.

29. Fraser R, Whitley GS, Thilaganathan B, Cartwright JE. Decidual natural killer cells regulate vessel stability: implications for impaired spiral artery remodelling. J Reprod Immunol. 2015;110:54-60.

30. Koo HS, Kwak-Kim J, Yi HJ, Ahn HK, Park CW, Cha SH, et al. Resistance of uterine radial artery blood flow was correlated with peripheral blood NK cell fraction and improved with low molecular weight heparin therapy in women with unexplained recurrent pregnancy loss. Am J Reprod Immunol. 2015;73(2):175-84.

31. Lyall F, Robson SC, Bulmer JN. Spiral artery remodeling and trophoblast invasion in preeclampsia and fetal growth restriction: relationship to clinical outcome. Hypertension. 2013;62(6):1046-54.

32. Hashemi V, Dolati S, Hosseini A, Gharibi T, Danaii S, Yousefi M. Natural killer T cells in Preeclampsia: An updated review. Biomed \& pharmacother $=$ Biomed \& pharmacoth. 2017;95:412-8.

33. Rizzo R, Lo Monte G, Bortolotti D, Graziano A, Gentili V, Di Luca D, et al. Impact of soluble HLA-G levels and endometrial NK cells in uterine flushing samples from primary and secondary unexplained infertile women. Int J Mol Sci. 2015;16(3):5510-6

34. Johnson KL, Bianchi DW. Fetal cells in maternal tissue following pregnancy: what are the consequences? Hum Reprod Update. 2004;10(6):497-502.

35. Ariga $\mathrm{H}$, Ohto H, Busch MP, Imamura S, Watson R, Reed W, et al. Kinetics of fetal cellular and cell-free DNA in the maternal circulation during and after pregnancy: implications for noninvasive prenatal diagnosis. Transfusion. 2001:41(12):1524-30.
36. Zhong XY, Holzgreve W, Hahn S. Circulatory fetal and maternal DNA in pregnancies at risk and those affected by preeclampsia. Ann N Y Acad Sci. 2001;945:138-40.

37. Khosrotehrani K, Johnson KL, Lau J, Dupuy A, Cha DH, Bianchi DW. The influence of fetal loss on the presence of fetal cell microchimerism: a systematic review. Arthritis Rheum. 2003;48(11):3237-41.

38. Leung TN, Zhang J, Lau TK, Chan LY, Lo YM. Increased maternal plasma fetal DNA concentrations in women who eventually develop preeclampsia. Clin Chem. 2001:47(1):137-9.

39. Lo YM, Leung TN, Tein MS, Sargent IL, Zhang J, Lau TK, et al. Quantitative abnormalities of fetal DNA in maternal serum in preeclampsia. Clin Chem. 1999;45(2):184-8.

40. Girardi G, Yarilin D, Thurman JM, Holers VM, Salmon JE. Complement activation induces dysregulation of angiogenic factors and causes fetal rejection and growth restriction. J Exp Med. 2006:203(9):2165-75.

41. Germain SJ, Sacks GP, Sooranna SR, Sargent IL, Redman CW. Systemic inflammatory priming in normal pregnancy and preeclampsia: the role of circulating syncytiotrophoblast microparticles. J Immunol. 2007;178(9):5949-56.

42. Gerber S, Vardhana S, Meagher-Villemure K, Vial Y, Hohlfeld P, Witkin SS. Association between fetal interleukin-1 receptor antagonist gene polymorphism and unexplained fetal death. Am J Obstet Gynecol. 2005; 193(4):1472-7.

43. Weintraub AY, Sheiner E, Bashiri A, Shoham-Vardi I, Mazor M. Is there a higher prevalence of pregnancy complications in a live-birth preceding the appearance of recurrent abortions? Arch Gynecol Obstet. 2005;271(4):350-4.

44. Nielsen HS, Mortensen L, Nygaard U, Schnor O, Christiansen OB, Andersen AM. Brothers and reduction of the birth weight of later-born siblings. Am J Epidemiol. 2008;167(4):480-4.

45. Bianchi DW, Zickwolf GK, Weil GJ, Sylvester S, DeMaria MA. Male fetal progenitor cells persist in maternal blood for as long as 27 years postpartum. Proc Natl Acad Sci U S A. 1996;93(2):705-8.

46. Gregory CD, Lee H, Rees GB, Scott IV, Shah LP, Golding PR. Natural killer cells in normal pregnancy: analysis using monoclonal antibodies and singlecell cytotoxicity assays. Clin Exp Immunol. 1985;62(1):121-7.

47. Groer MW, El-Badri N, Djeu J, Williams SN, Kane B, Szekeres K. Suppression of natural killer cell cytotoxicity in postpartum women: time course and potential mechanisms. Biol Res Nurs. 2014;16(3):320-6.

48. Choi J, Lee SJ, Lee YA, Maeng HG, Lee JK, Kang YW. Reference values for peripheral blood lymphocyte subsets in a healthy korean population. Immune Netw. 2014;14(6):289-95.

49. Ilavska S, Horvathova M, Szabova M, Nemessanyi T, Jahnova E, Tulinska J, et al. Association between the human immune response and body mass index. Hum Immunol. 2012;73(5):480-5.

50. Valiathan R, Deeb K, Diamante M, Ashman M, Sachdeva N, Asthana D. Reference ranges of lymphocyte subsets in healthy adults and adolescents with special mention of T cell maturation subsets in adults of South Florida. Immunobiology. 2014;219(7):487-96.

51. Laird SM, Mariee N, Wei L, Li TC. Measurements of CD56+ cells in peripheral blood and endometrium by flow cytometry and immunohistochemical staining in situ. Hum Reprod Oxford. 2011;26(6):1331-7.

\section{Publisher's Note}

Springer Nature remains neutral with regard to jurisdictional claims in published maps and institutional affiliations.

Ready to submit your research? Choose BMC and benefit from:

- fast, convenient online submission

- thorough peer review by experienced researchers in your field

- rapid publication on acceptance

- support for research data, including large and complex data types

- gold Open Access which fosters wider collaboration and increased citations

- maximum visibility for your research: over $100 \mathrm{M}$ website views per year

At $\mathrm{BMC}$, research is always in progress.

Learn more biomedcentral.com/submissions 